\title{
Yield and nutritive value of selected endive cultivars grown for spring and autumn harvest
}

\author{
Cecylia Miłowana Uklańska-Pusz, Katarzyna Adamczewska-Sowińska \\ Department of Horticulture \\ Wrocław University of Environmental and Life Sciences \\ Grunwaldzki Sq. 24A, 50-363 Wrocław, Poland \\ e-mail: cecylia.uklanska@up.wroc.pl
}

\begin{abstract}
A field experiment was carried out in the years 2007-2009 at the Research Development Station of the Department of Horticulture at the Wrocław University of Environmental and Life Sciences. The experiment involved two botanical varieties of endive: var. latifolium (nine cultivars) and var. crispum (five cultivars). Endive was cultivated from transplants produced in a greenhouse in two terms, for spring and autumn harvesting. The harvest took place 90-100 days after the seeds were sown. In the course of harvesting, the total and marketable yields were determined, while biological value was assessed on the basis of analyses regarding the content of dry matter, vitamin $\mathrm{C}$, chlorophyll and carotenoids, as well as the amounts of such elements as $\mathrm{Mg}, \mathrm{P}, \mathrm{K}, \mathrm{Ca}$ and nitrates.
\end{abstract}

Key words: biological value, botanical variety, Cichorium endivia, term of planting

\section{INTRODUCTION}

Endive (Cichorium endivia L.) is a vegetable that belongs to the greens group, relatively little known in Poland, while it has been commonly cultivated and eaten in the countries of Western Europe, like Italy, France, Holland or Spain (Ryder 1999). The nutritive value of endive is higher in comparison to head lettuce and, therefore, making its cultivation more popular is, obviously, recommendable. Leafy vegetables belong to a group of healthier foods, with high potential for human health as a source of vitamins and antioxidant compounds, like polyphenols (Llorach et al. 2008). However, they also contain undesirable substances, like nitrates (Reininik et al. 1994, Santamaria 2006). Quality and quantity are important for producers and consumers and the cultivation term has a considerable influence on these traits. The additional advantages of endive include its modest thermic requirements and the plant growing period, averaging 90 days from sowing to harvesting its rosettes, comparable to lettuce.
In the conditions of Lower Silesia, endive can be grown even for November harvesting, without the use of any covers. In earlier cultivation terms, some cultivars are susceptible to inflorescence shooting, because endive is an annual, long-day plant. Shooting in the inflorescence stems can cause lower marketable yields of the crop and may also exclude some cultivars from a spring or summer crop (Trautwein 1999, Rodkiewicz 2000).

The aim of the research was the assessment of yielding and the biological value of different endive cultivars grown from transplants for spring and autumn harvest.

\section{MATERIAL AND METHODS}

A two-factorial field experiment was conducted in the years 2007-2009 at the Research and Development Station for Vegetables and Ornamental Plants in Psary. The study covered two terms of endive cultivation, for spring and autumn harvest, which was the first factor of the experiment. The 
Table 1. Terms of endive sowing, transplant planting and harvesting in the years 2007-2009

\begin{tabular}{ccccccc}
\hline \multirow{2}{*}{ Year } & \multicolumn{2}{c}{ Sowing } & \multicolumn{2}{c}{ Planting } & \multicolumn{2}{c}{ Harvest } \\
\cline { 2 - 7 } & I & II & I & II & I & II \\
\hline 2007 & 26.02. & 26.07. & 12.04. & 28.08. & 10.06. & 14.11. \\
2008 & 20.02. & 18.07. & 04.04. & 18.08. & 04.06. & 27.10. \\
2009 & 27.02. & 30.07. & 20.04. & 26.08. & 08.06. & 12.11. \\
\hline
\end{tabular}

I - cultivation for spring harvest

II - cultivation for autumn harvest

experiment tested 14 endive cultivars, both those available on Polish market and ones imported from France, Spain and Italy, out of which nine ('Jennifer', 'Kimberly', 'Tosca', 'Ariga', 'Minerva', 'De Meaux', 'Cigal', 'Estival', 'Fildor') belong to the botanical variety of curly leaves (Cichorium endivia var. crispum) and the remaining cultivars ('Excel', 'Douchka', 'Natacha', 'Kalinka', 'Delta') represent the escarole endive with smooth leaves (Cichorium endivia var. latifolium).

The seeds were sown in $54 \mathrm{~cm}^{3}$ multipots filled with a peat substrate. The plants were left in a greenhouse until they reached the 4-5 mature leaf stage and, after hardening, they were planted in $4.2 \mathrm{~m}^{2}(2 \times 2.1 \mathrm{~m})$ plots, in spacing of $40 \times 35 \mathrm{~cm}$. Nitrogen fertilisation in the amount of $80 \mathrm{~kg} \mathrm{ha}^{-1}$ in the form of ammonium nitrate was applied prior to planting. The field experiment was established according to a randomised split-plot method, in three replications, on degraded black earth class III a. The periods of sowing, planting and harvesting are shown in Table 1.

The biological value of the rosettes collected at the beginning of June and at the turn of October and November was assessed on the basis of chemical analyses of the fully developed internal leaves from six plants. Vitamin C content was determined with the titrimetric method using 2.6-dichloroindophenol, chlorophyll and carotenoids with the colorimetric method, and dry matter with the gravimetric method at $105^{\circ} \mathrm{C}$. Macroelements and nitrates were assayed using Nowosielski's universal method, $\mathrm{Mg}$ and $\mathrm{Ca}$ with the colorimetric method, while $\mathrm{P}$ and $\mathrm{K}$ were determined through the method of flame photometry. Nitrate content was determined according to the potentiometric method.

The results were subjected to statistical analysis comparing mean values with the use of the Tukey test, at a significance level of $p=0.05$.

\section{RESULTS AND DISCUSSION}

On the basis of the obtained results it is possible to state that in all of the experimental years, the cultivation period and cultivar did significantly affect the marketable yield size (Tab. 2). The autumn term of cultivation resulted in an increased marketable yield share of total yield in the studied cultivars (Fig. 1). In every year of the study, it was concluded that the marketable yield of the cultivars with a high tendency towards inflorescence shooting ('Kimberly', 'Tosca', 'Ariga', 'Minerva', 'De Meaux', 'Estival', 'Fildor', 'Douchka' and 'Delta') was lower in the autumn term. Only five of the 14 studied cultivars ('Jennifer', 'Cigal', 'Excel', 'Natacha' and 'Kalinka') were tolerant to day length, characterised by longer growth period. Endives, especially from var. crispum, that are grown in the spring term are prone to shooting in the inflorescence stems, which was confirmed in our research. Low temperatures during the production of seedlings and long days accelerate the transition of plants from the vegetative to the generative phase (Trautwein 1999).

In research by Rodkiewicz (2000), very high yields, between 44-78 $\mathrm{tha}^{-1}$, were obtained for the 'Bossa' cultivar. Similar yield size of endive (53 $\left.-66 \mathrm{t} \mathrm{ha}^{-1}\right)$ was reported by Koudela and Petřikowà (2007), whose experimental data for marketable yield were as high as $41 \mathrm{tha}^{-1}$.

The average marketable yield for the studied endive cultivars in the years 2007-2009 equalled $15.68 \mathrm{t} \mathrm{ha}^{-1}$ for the spring term, and was $41.5 \%$ lower than the autumn marketable yield. In the first two years of the experiment, the marketable yield size in autumn cultivation was higher than that obtained from the first cultivation term by 160 and $89 \%$. In 2009 , the aforementioned yield maintained the same level of significance in both harvest terms. The average marketable yield in autumn 2009 was only $17.44 \mathrm{t} \mathrm{ha}^{-1}$. Such a considerable decrease, as compared to previous experimentalyears, was caused by intensive feeding of hares on the investigated treatment, as well as a profound devastation of inner, young leaves, which favoured rapid development of bacterial diseases. Amongst the studied cultivars, the highest yielding (mean values for three years) was recorded for the 'Kalinka' cultivar 
$-28.79 \mathrm{t} \mathrm{ha}^{-1}$. The latter belongs to the escarole endive group, characterised by smooth leaves and the formation of large rosettes, with a well-coloured light heart. The worst yielding cultivars in the spring term proved to be 'Tosca' (only $5.06 \mathrm{t} \mathrm{ha}^{-1}$ ) and 'Ariga' $\left(7.06 \mathrm{t} \mathrm{ha}^{-1}\right)$, while in the second term the lowest yield values came from the 'Tosca' cultivar $\left(10.29 \mathrm{t} \mathrm{ha}^{-1}\right)$, classified, according to some sources, to the "baby endive" type, since its rosettes do not exceed the weight of 200-250 g (Anonim 2002). The share of marketable yield in the total yield in the spring and autumn terms ranged from 22.5 and $51.6 \%$ for the 'Tosca' cultivar to 78.5 to $97.5 \%$ for the 'Kalinka' cultivar (Fig. 1). The smallest differences between marketable and total yield in both terms were observed for cultivars resistant to florescence shooting ('Jennifer' and 'Cigal'), belonging to the crispum group, which provided for $22 \%$ of the examined cultivars from this group, as well as 'Excel', 'Natacha' and 'Kalinka' from the latifolium group, constituting $60 \%$. Rodkiewicz (2000), like the authors of this research, also obtained a higher share of marketable yield in total yield in later terms of endive cultivation.

Chemical analyses done to determine biological value proved that both cultivation term and cultivar did significantly affect vitamin $\mathrm{C}$ content, chlorophyll, carotenes, macroelements and nitrates in this plant (Tabs 3 and 4). The cultivar was the only factor that resulted in the occurrence of statistically significant differences in dry matter content. Comparing the two groups of endive cultivars - curly leaves and escarole - the former contained higher amounts of dry matter ( $8.6 \%)$ than the latter $(7.72 \%)$. The lowest content of dry matter was found in the 'Delta' cultivar, while the highest belonged to the 'De Meaux' cultivar. Vitamin C content averaged $35.35 \mathrm{mg} 100 \mathrm{~g}^{-1}$ f.m. As far as vitamin $\mathrm{C}$ content in spring cultivation is concerned, its values ranged from 29.91 to $41.98 \mathrm{mg} 100 \mathrm{~g} \mathrm{~g}^{-1}$ f.m., while in the autumn it ranged from 24.62 to $48.31 \mathrm{mg} 100 \mathrm{~g}^{-1} \mathrm{f} . \mathrm{m}$. The lowest quantities of this vitamin in both cultivation terms were found in the 'Tosca' cultivar. The 'Kimberly' cultivar contained $53 \%$ more and, at the same time, the highest quantities of vitamin $\mathrm{C}$ amongst all of the studied cultivars. Koudela and Petřiková (2007) found that vitamin $\mathrm{C}$ content was as low as $14.5-28.2 \mathrm{mg}$ $100 \mathrm{~g}^{-1} \mathrm{f}$.m. in the autumn-cultivated endive. The average chlorophyll content was about $21 \%$ higher in the spring term as compared to the autumn term and it equalled as follows: from $0.759 \mathrm{mg} \mathrm{g}^{-1} \mathrm{f} . \mathrm{m}$. in the 'Tosca' cultivar to $1.030 \mathrm{mg} \mathrm{g}^{-1} \mathrm{f} . \mathrm{m}$. in the 'Fildor' cultivar in spring cultivation, while in the autumn the 'Kalinka' cultivar ( $0.650 \mathrm{mg} \mathrm{g}^{-1}$ f.m.) had the lowest value and the 'De Meaux' cultivar had the highest one. Regardless of the cultivation term, cultivars of curly leaf endive contained the highest amounts of chlorophyll in their leaves. The mean value of carotene content was $3.12 \mathrm{mg} \mathrm{g}^{-1}$

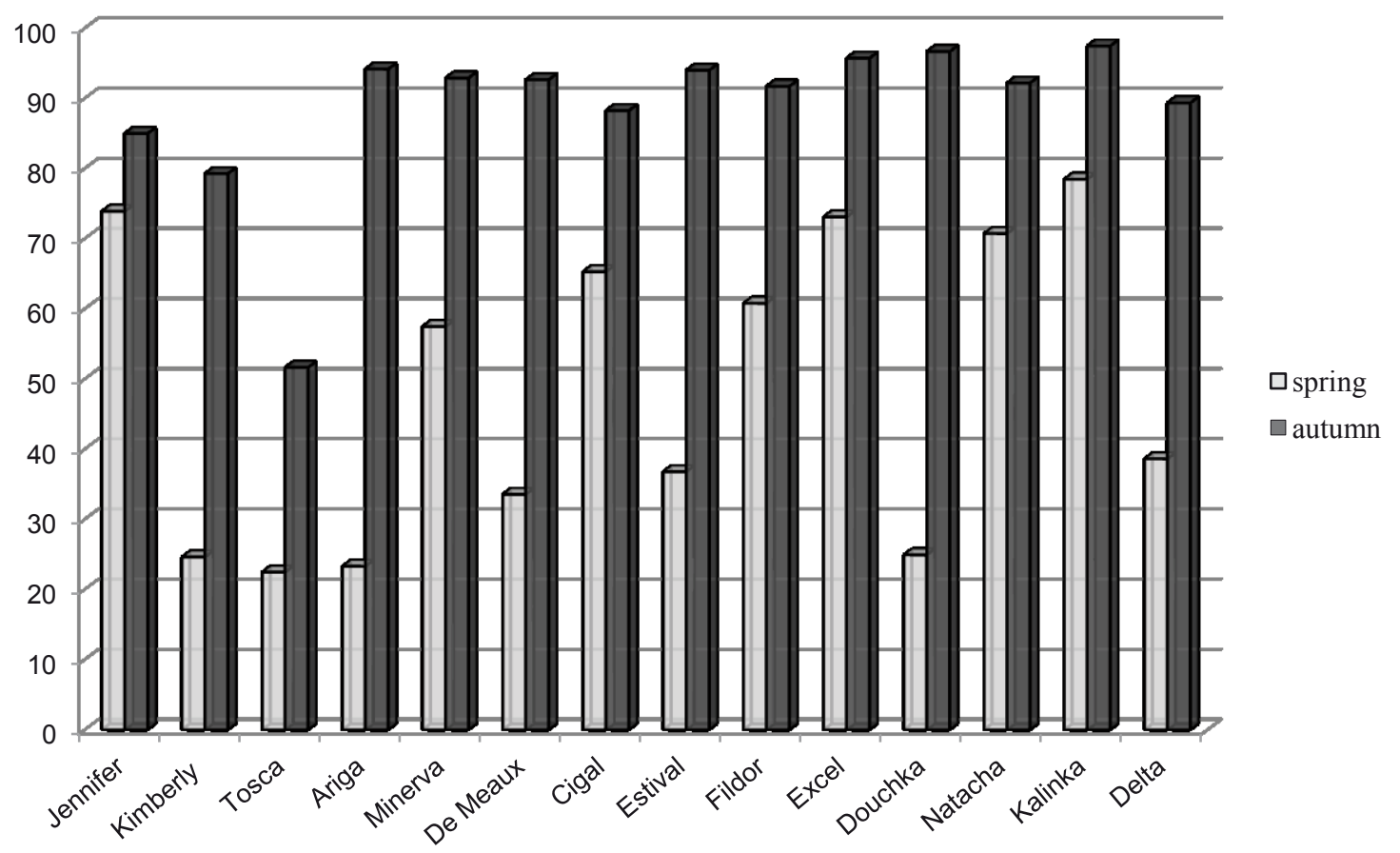

Figure 1. Average share of marketable yield in total yield of the tested endive cultivars in the years 2007-2009 (\%) 


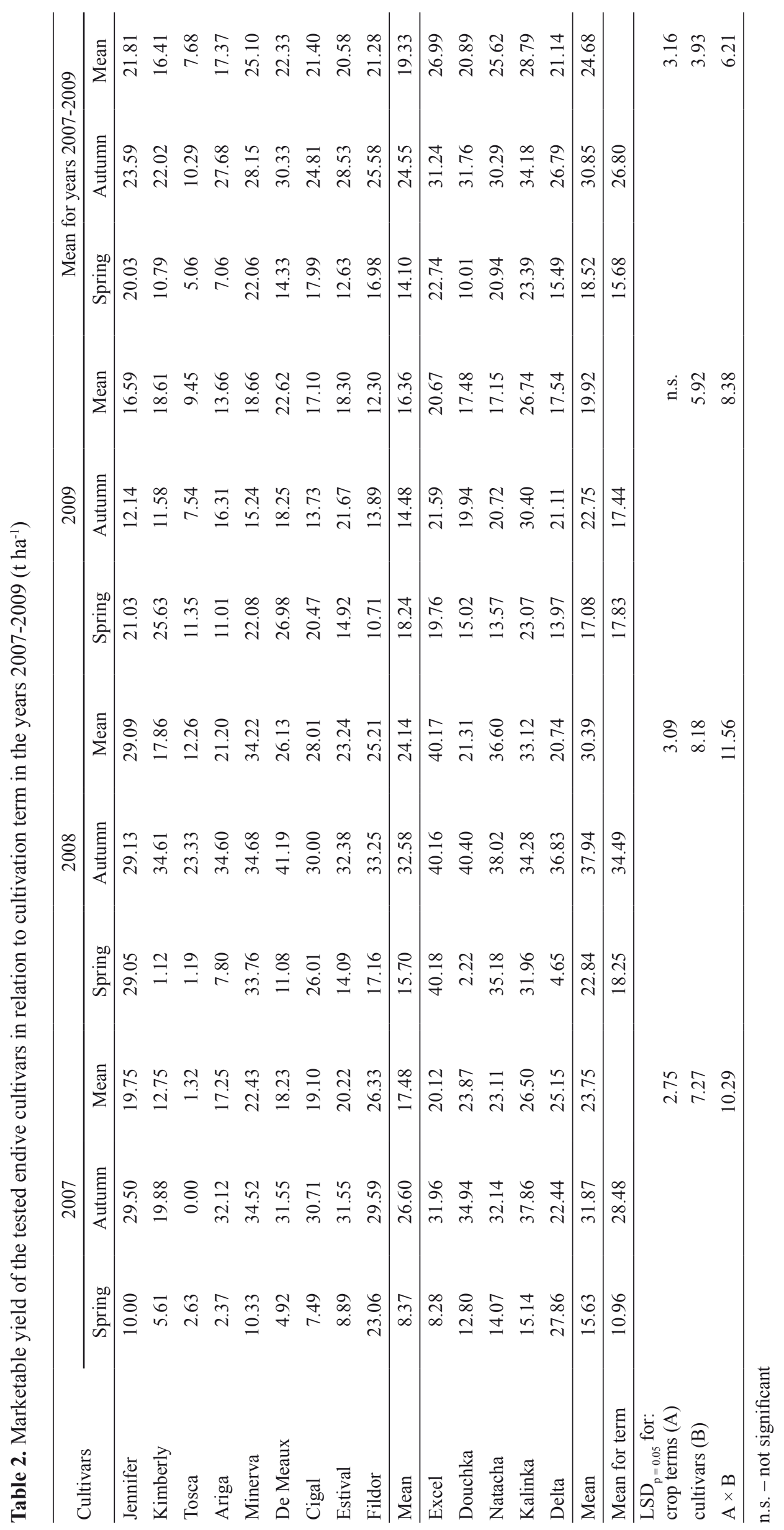




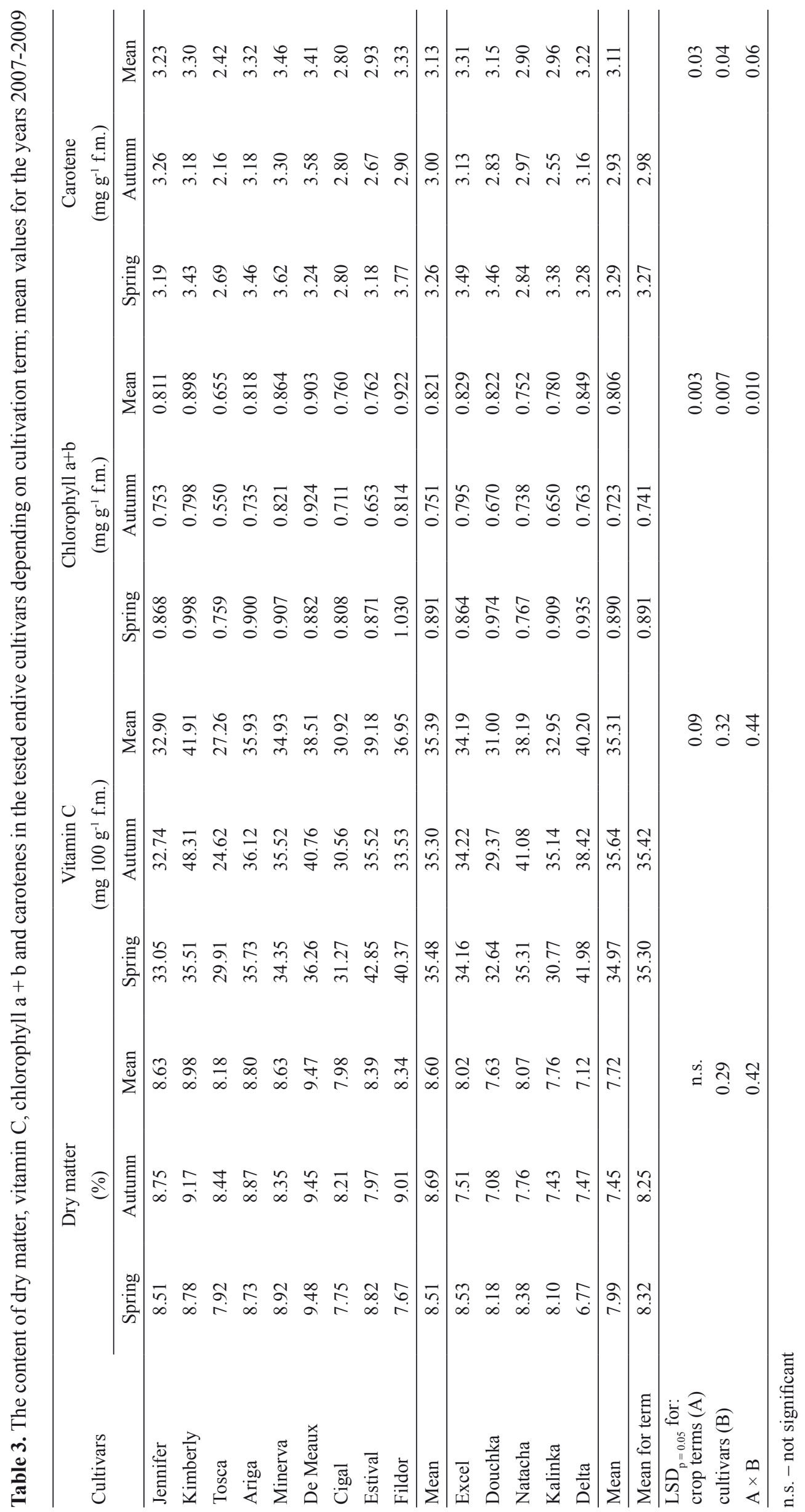




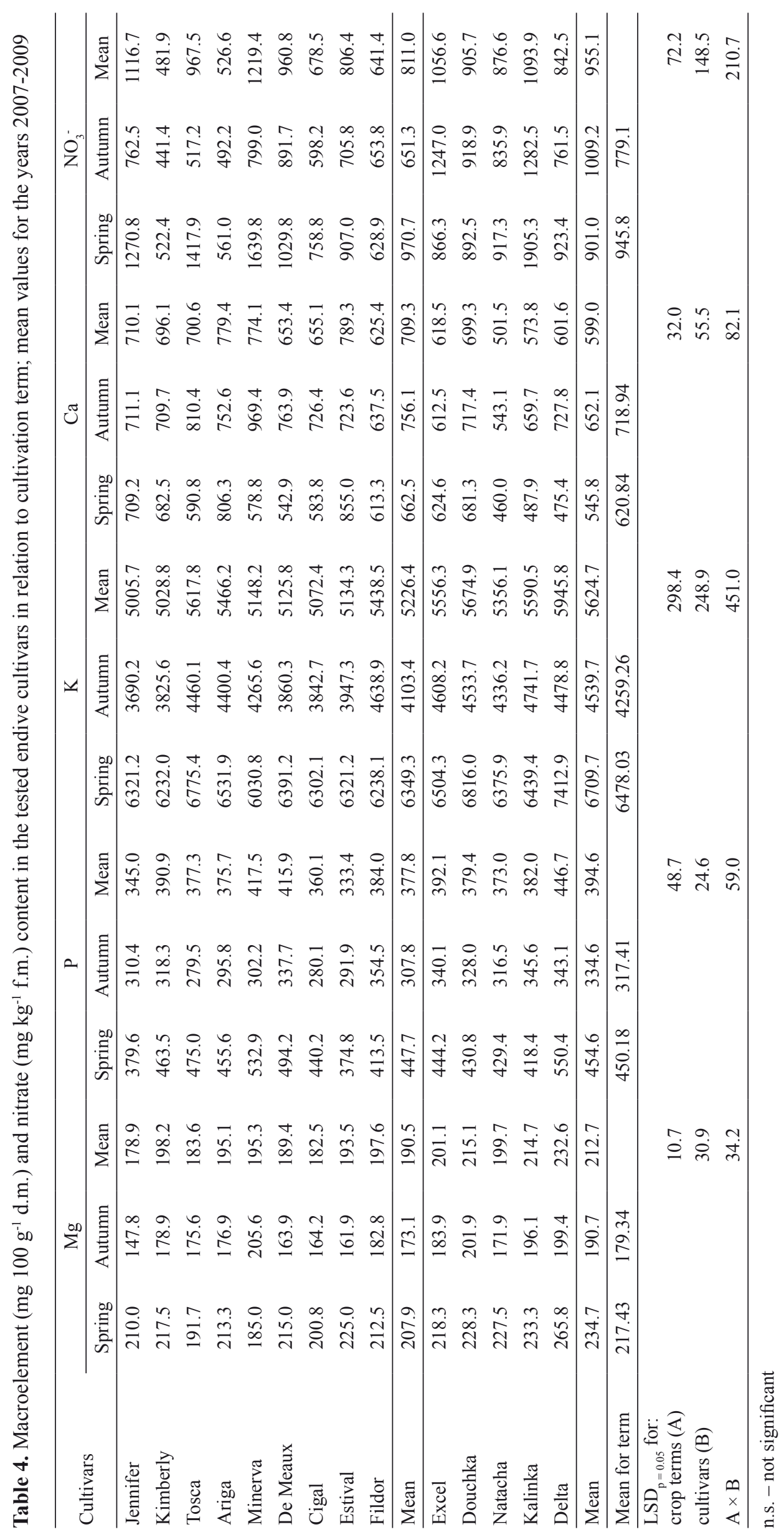


f.m., and in the case of the first cultivation term it was higher by $10 \%$ on average. The 'Tosca' cultivar accumulated the least amount of carotene $(2.42$ $\mathrm{mg} \mathrm{g}^{-1}$ f.m.), while the highest quantities of this component were found in the 'Minerva' cultivar (3.46 $\mathrm{mg} \mathrm{g}^{-1}$ f.m.).

An assessment of macroelement content proved that during the spring cultivation term, endive leaves contained $22 \%$ more magnesium, a $29 \%$ higher quantity of phosphorus and a $34 \%$ higher amount of potassium. Cultivars belonging to the escarole group contained $12 \%$ more magnesium in the leaves on average. The 'Delta' cultivar had the highest levels of this macroelement content during spring cultivation, while the 'Minerva' cultivar contained the most of the autumn cultivated plants. A positive influence of later cultivation term on increased calcium content and on decreased amounts of nitrates was observed in a majority of the researched cultivars. Higher quantities of calcium and lower nitrate content were found in the group of curly leaf endive cultivars than in cultivars of the escarole endive group. The lowest degree of nitrate accumulation was found in such cultivars as 'Kimberly', 'Estival', 'Fildor' (curly leaf cultivars) and 'Douchka' and 'Natacha' (escarole cultivars). Koudela and Petrriková (2007) also observed an increased tendency towards nitrate accumulation in the leaves of the escarole endive group in comparison to cultivars from curly leaf endive cultivars. Yet in their research involving 23 cultivars, Reininik et al. (1994) failed to prove any relationship between botanical variety and tendency towards an excessive accumulation of nitrates. Polish law does not provide for the maximum level of nitrate content for endive, as it refers only to basic species of greens. In other European countries, the maximum nitrate level in endive leaves was determined as 2,500 $\mathrm{mg}$ $\mathrm{kg}^{-1}$ f.m. (Santamaria 2006), similar to lettuce. The abovementioned level was not exceeded in our own investigation, and the highest nitrate content was more than twice lower than the level determined by law.

\section{CONCLUSIONS}

1. The significantly higher endive marketable yields during autumn cultivation and their more considerable contribution to endive total yield speaks in favour of this cultivation term in the conditions of Lower Silesia.

2. Broad-leaf endive cultivars had higher yield in both terms - lower in spring and higher in autumn cultivation in comparison to the curlyleaf cultivars.

3. Endive grown in the spring contains elevated amounts of chlorophyll, carotenes, magnesium, phosphorus and potassium.

4. Cultivars of curly leaf endive contained higher contents of dry matter, chlorophyll, carotenoids and calcium, as well as lower quantities of nitrates in comparison to the escarole endive. The latter contained elevated amounts of magnesium, phosphorus and potassium in the dry matter of their leaves.

\section{ACKNOWLEDGEMENTS}

The work was financed by the State Committee for Scientific Research (KBN) in the years 2008-2010 as research project No. N N310 148435.

\section{REFERENCES}

Anonim, 2002. Endive and escarole, Commercial Vegetable Production Guides. http://nwrec.hort. oregonstate.edu/endive.html (17.03.2010).

Koudela M., Petřiková K., 2007. Nutritional composition and yield of endive cultivars - Cichorium endivia L. Hort. Sci. 34(1): 6-10.

Llorach R., Martinez-Sanchez A., Tomas-Barberan F., Gil M.I, Ferres F., 2008. Charaterisation of polyphenols and antioxidant properties of five lettuce varieties and escarole. Food Chem. 108: 1028-1038.

Reininik K., Nes M., Groenwold R., 1994. Genetic Variation for Nitrate Content between Cultivars of Endive (Cichorium endivia L.). Euphytica 75: 41-48.

Rodkiewicz T., 2000. Wpływ terminu uprawy na plonowanie endywii (Cichorium endivia L. var. latifolium LAM.) Annales UMCS, Sectio EEE Vol. VIII, Suppl.: 205-210.

Ryder E.J., 1999. Lettuce, Endive and Chicory. CABI, New Jork.

Santamaria P., 2006. Nitrate in vegetables: toxicity, content, intake and EC regulation, review. Journal Sci. Food Agric. 86: 10-17.

Trautwein F., 1999. Schossfestigkeit von Endiviensorten getestet. Gemüse 10: 582 .

\section{PLONOWANIE I WARTOŚĆ ODŻYWCZA WYBRANYCH ODMIAN ENDYWII W UPRAWIE NA ZBIÓR WIOSENNY I JESIENNY}

Streszczenie: Doświadczenie polowe przeprowadzono w latach 2007-2009 w Stacji BadawczoDydaktycznej Katedry Ogrodnictwa Uniwersytetu Przyrodniczego we Wrocławiu. Do badań wybrano odmiany należące do dwóch odmian botanicznych 
endywii: var. latifolium (9 odmian) i var. crispum (5 odmian). Endywia uprawiana była $\mathrm{z}$ rozsady wyprodukowanej szklarni $\mathrm{w}$ dwóch terminach: wiosennym i jesiennym. Zbiór następował po 90 -100 dniach od siewu nasion. W czasie zbiorów określono plon ogólny i handlowy, a wartość biologiczną oceniono na podstawie analiz dotyczących zawartości suchej masy, witaminy C, chlorofilu i karotenoidów oraz makroelementów $\mathrm{Mg}, \mathrm{P}, \mathrm{K}$ i Ca, a także azotanów.

Received April 6, 2010; accepted November 30, 2011 